\title{
Changes of testicular cholesteryl ester hydrolase activity in experimentally cryptorchid rats
}

\author{
Anna-Maria Hoffmann, A. Bergh* and T. Olivecrona \\ Departments of Physiological Chemistry and *Pathology, University of Umea, S-901 87 Umeå, \\ Sweden
}

\begin{abstract}
Summary. A simple and reliable method was developed to determine the neutral cholesteryl ester hydrolase $(\mathrm{CEH})$ activity in rat testes, using cholesteryl-[1- $\left.{ }^{14} \mathrm{C}\right]$-oleate as substrate. The activity was due to a soluble enzyme present in the cytoplasm of predominantly Sertoli cells, which could be shown after depleting the testes of Leydig cells with ethane dimethyl sulphonate. This treatment also revealed that the loss of CEH activity in abdominal testes of experimentally cryptorchid rats takes place in the Sertoli cells. In prepubertal rats made unilaterally cryptorchid at birth, the CEH activity was significantly higher in the abdominal than in the scrotal testes at 16 days of age. This is earlier than any previously described biochemical change and coincides with, or may even precede, the earliest morphological changes which are accumulation of lipid droplets in the Sertoli cells. The testicular CEH activity then decreased to 30 days of age in the abdominal testes, whereas the activity increased in the contralateral, scrotal testes. When adult rats were made unilaterally cryptorchid for $24 \mathrm{~h}$, the CEH activity decreased rapidly in the abdominal testes. These results suggest that a derangement in cholesteryl ester metabolism is an early event in the pathogenesis of testicular degeneration in cryptorchidism.
\end{abstract}

Keywords: testis; Sertoli cell; cryptorchidism; enzyme activity; assay; ethane dimethyl sulphonate

\section{Introduction}

Several studies have shown that the levels of testicular lipids change after treatments that impair spermatogenesis (Davis \& Coniglio, 1967; Fleeger et al., 1968a,b). One such condition is cryptorchidism, which is generally thought to produce its degenerative effect by elevation of testicular temperature (VanDemark et al., 1970; Blackshaw, 1977). However, the mechanisms by which temperature damages testicular function remain obscure.

Experimental cryptorchidism can be induced in newborn rats by preventing testicular descent (Bergh et al., 1978). In this model, called primary experimental cryptorchidism, the earliest morphological change in the abdominal testes is an increased concentration of lipid droplets in the cytoplasm of Sertoli cells. This is noted at 16 days of age, the first time at which a temperature difference between the descending testis and the abdomen can be measured. At this age, no structural differences between germinal cells in the abdominal and scrotal testes are observed (Bergh, 1983). At 20 days the lipid accumulation in Sertoli cells is more pronounced, and degenerating germinal cells are noted (Bergh, 1983). With time, these differences become more pronounced, and the degeneration of the abdominal testes results in a difference in testicular weight, and decreased Leydig cell testosterone secretion (Bergh \& Damber, 1978; Bergh \& Helander, 1978; Bergh, 1983).

When cryptorchidism is induced in adult rats (secondary experimental cryptorchidism), an increased lipid concentration in the abdominal testes has been demonstrated by histochemical techniques (McEnery \& Nelson, 1953). Direct determinations have shown that the cholesteryl ester 
concentration is increased (Johnson et al., 1971). By analogy, the lipid accumulation in primary experimental cryptorchidism may also be due, at least in part, to cholesteryl esters. Cholesteryl esters serve as a storage form of cholesterol, which can be drawn upon for steroid hormone biosynthesis (Bartke et al., 1973; Moyle et al., 1973; Saksena et al., 1974). Cholesteryl ester hydrolase (EC 3.1.1.13) is therefore a potential regulator of steroidogenesis (Rommerts et al., 1980) and of lipid composition in the testes. There have been reports that the activity of this enzyme is decreased in secondary cryptorchidism, and, moreover, that this enzyme is directly inactivated at abdominal temperatures (Durham \& Grogan, 1982). The aim of this study was to develop a simple and reliable assay for cholesteryl ester hydrolase activity in the testes, and to follow the activity in prepubertal unilaterally cryptorchid rats.

\section{Materials and Methods}

\section{Animal and tissue preparations}

Experimental cryptorchidism. The lower part of the gubernaculum testis was cut unilaterally in newborn SpragueDawley rats to prevent subsequent testicular descent and scrotal development, which normally start within 1 week of birth and are completed at about 35 days of age (Bergh \& Helander, 1978). The operated rats were raised together with their mothers, and artificial daylight was provided for $12 \mathrm{~h}$ per day. The animals were used in experiments when 16,20 or 30 days or 3 months old. Experimental unilateral cryptorchidism was also induced in 3-month-old rats by suturing one testis to the dorsolateral wall, as previously described (Bergh \& Damber, 1984). The animals were used for experiments $24 \mathrm{~h}$ later.

Treatment with ethane dimethyl sulphonate (EDS). Adult, 3-month-old control and primary unilaterally cryptorchid rats were treated with $30 \mathrm{mg}$ EDS/ml dimethyl sulphoxide- $\mathrm{H}_{2} \mathrm{O}(1: 3 \mathrm{v} / \mathrm{v})$, administered by intraperitoneal injection $(75 \mathrm{mg} / \mathrm{kg}$ body weight $)$. Other rats were injected with the vehicle alone. After 3 days the animals were used in experiments. EDS treatment, by mechanisms unknown, leads to total depletion of Leydig cells from the testis (Jackson \& Morris, 1977; Morris et al., 1986). To verity that this was the case also in our intact and unilaterally cryptorchid rats, testes from EDS-treated animals were fixed in Bouin's solution and embedded in methacrylate resin (Histo-Resin, LKB, Stockholm, Sweden).

The animals were killed and both testes were removed, freed from the epididymis and the surrounding fat pads, and were immediately frozen and stored at $-80^{\circ} \mathrm{C}$ until prepared for assay. Control experiments showed that freezing of the tissue did not change the activity of the cholesteryl ester hydrolase.

Each testis was rinsed and weighed. It was then homogenized in 10 parts ice-cold $20 \mathrm{~mm}$-Tris- $\mathrm{HCl}$ buffer $\mathrm{pH} 7 \cdot 4$, $0 \cdot 15 \mathrm{M}-\mathrm{NaCl}, 1 \mathrm{~mm}-\mathrm{EDTA}$, in a tissue grinder with a loose Teflon pestle. This preparation was centrifuged for $15 \mathrm{~min}$ in a Beckman Minifuge at $4^{\circ} \mathrm{C}$ to remove cell debris, or centrifuged at $100000 \mathrm{~g}$ in a Beckman ultracentrifuge for $2 \mathrm{~h}$ at $4^{\circ} \mathrm{C}$. The supernatant $(\mathrm{S}-100)$ was recovered, and extracted at $10^{\circ} \mathrm{C}$ with $n$-hexane $(1: 1 \mathrm{v} / \mathrm{v})$ to remove endogenous lipids. Such fat-depleted S-100 preparations were used for enzyme characterization.

Protein content in the aqueous layer was determined by the method of Lowry et al. (1951), using bovine serum albumin as a standard.

\section{Enzyme assay and incubation procedure}

The activity of cholesteryl ester hydrolase was measured as release of fatty acid from labelled cholesteryl ester. For this, cholesteryl oleate was chosen since it is the principal ester of cholesterol in the testis (Saksena et al., 1974). To prepare a substrate emulsion, $35 \mu \mathrm{g}$ cholesteryl- $\left[{ }^{14} \mathrm{C}\right]$-oleate in toluene were added to $1 \mathrm{ml} 0 \cdot 10 \mathrm{M}$-sodium phosphate buffer $\mathrm{pH} 7.4,0.15 \mathrm{M}-\mathrm{NaCl}, 1 \mathrm{~mm}$-EDTA. After evaporation of the toluene the mixture was sonicated for $10 \mathrm{~min}$ ( $5 \mathrm{~min}$ at room temperature, $5 \mathrm{~min}$ on ice) in a Branson Sonifier type $\mathrm{B}_{12}$. To $100 \mu \mathrm{l}$ of this mixture was added enzyme source and/or corresponding buffer to make a total volume of $200 \mu \mathrm{l}$. The final $\mathrm{pH}$ was $7 \cdot 4$, the salt concentration was $0 \cdot 15 \mathrm{M}$.

The incubations were carried out with shaking in a waterbath at $25^{\circ} \mathrm{C}$. The reaction was stopped and the labelled free fatty acids were isolated by a one-step liquid-liquid partition system as described by Belfrage \& Vaughan (1969), but with $0.1 \mathrm{M}$-potassium carbonate buffer $\mathrm{pH} 10 \cdot 5$.

All incubations were carried out in triplicate. The enzymic activity is expressed in $\mathrm{mU}$, equivalent to nmol cholesteryl oleate hydrolysed per min at $25^{\circ} \mathrm{C}$ unless otherwise indicated.

\section{Chemicals}

Cholesteryl- $\left[{ }^{14} \mathrm{C}\right]$-oleate (sp. act. $56 \mathrm{mCi} / \mathrm{mmol}$ ) was obtained from Amersham International (Amersham, Bucks, UK). Bovine serum albumin (fraction V) and diethyl-p-nitrophenyl-phosphate (DNP) were from Sigma Chemical Co. 
(St Louis, MO, USA). Phenyl methyl sulphonyl fluoride (PMSF) was from Serva Feinbiochemica (Heidelberg, West Germany). EDS was kindly donated by Dr F. F. G. Rommerts (Department of Biochemistry, Erasmus University, Rotterdam, The Netherlands).

\section{Results}

\section{Characteristics of cholesteryl ester hydrolase activity}

The enzyme activity showed a rather broad $\mathrm{pH}$ optimum centered around $\mathrm{pH} 7 \cdot 4$ (Fig. 1a). The reaction rate increased with the substrate concentration and plateaued at about $27 \mu \mathrm{M}$-cholesteryl oleate (Fig. 1b). Larger amounts of substrate did not inhibit the reaction. The data in Fig. 1(b) fit the Michaelis-Menten equation, and yield an apparent $K_{\mathrm{m}}$ of $13 \mu \mathrm{M}$. The rate of hydrolysis increased linearly with the amount of enzyme source at least up to $250 \mu \mathrm{g}$ protein $/ 200 \mu \mathrm{l}$ incubation mixture (Fig. 1c), and the reaction was linear with time for at least $90 \mathrm{~min}$ (Fig. 1d).
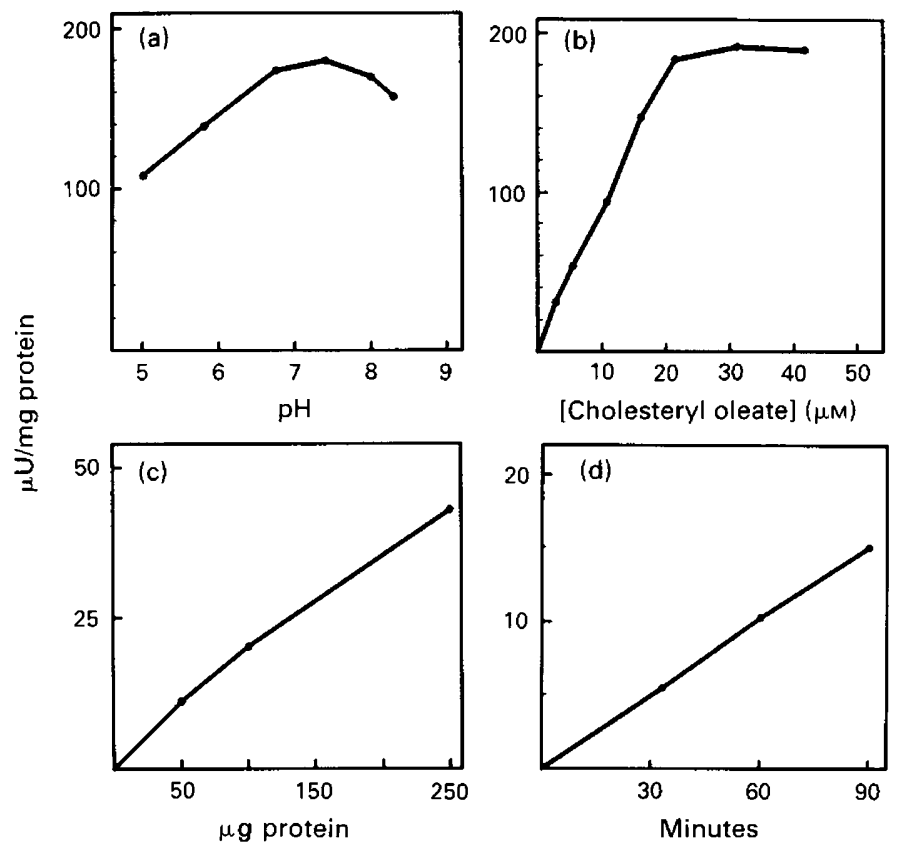

Fig. 1. Determination of optimal conditions ((a) $\mathrm{pH}$; (b) substrate concentration; (c) protein concentration; (d) incubation time) for the assay of neutral cholesteryl ester hydrolase activity of rat testicular tissue. Except for the factors being varied, each incubation was carried out as described in 'Materials and Methods': $1 \mathrm{mU}$ is equivalent to $1 \mathrm{nmol}$ cholesteryl oleate hydrolysed $/ \mathrm{min}$ at $25^{\circ} \mathrm{C}$.

We therefore chose the following standard conditions for the assay: 5-10 $\mu$ l of enzyme source, and $3.5 \mu \mathrm{g}$ labelled cholesteryl oleate, in a total volume of $200 \mu \mathrm{l}$. Incubation was for $30 \mathrm{~min}$ at $25^{\circ} \mathrm{C}$.

The activity of the enzyme was inhibited more than $98 \%$ by DNP and by PMSF. A $50 \%$ inhibition required a concentration of about $140 \mathrm{nM}$ and $40 \mu \mathrm{M}$ respectively (Fig. 2). PMSF is a serine hydrolase inhibitor that has previously been found to inhibit the activity of cholesteryl ester hydrolase in some other tissues (Fredrikson et al., 1981). 

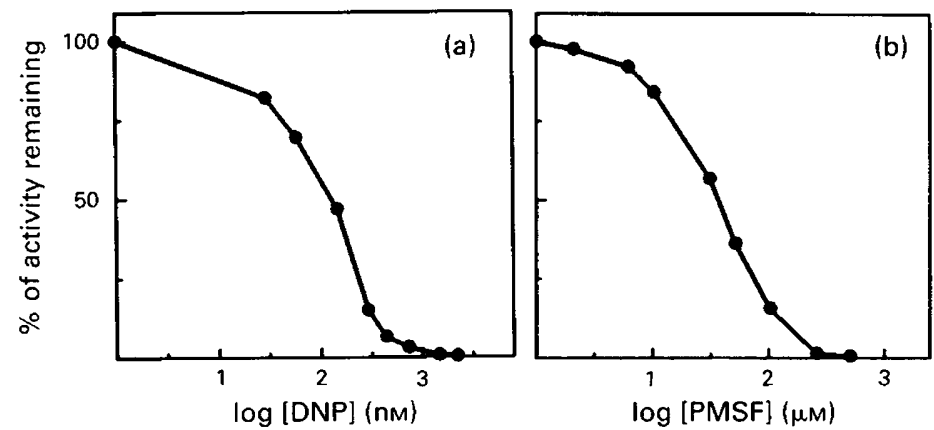

Fig. 2. Effect of serine-hydrolase inhibitors (a, DNP; b, PMSF) on testicular cholesteryl ester hydrolase activity. Incubations were carried out in triplicate at the indicated concentrations.

Subcellular localization of the cholesteryl ester hydrolase activity, and effects of physical treatments

More than $90 \%$ of the activity in testicular homogenates remained in the supernatant after centrifugation for $2 \mathrm{~h}$ at $100000 \mathrm{~g}$. Centrifugation in a Beckman Minifuge for $15 \mathrm{~min}$ was sufficient to remove cell debris, and was therefore used for the studies of changes of enzyme activity in prepubertal cryptorchidism. Homogenates prepared in Tris or in phosphate buffer gave the same activity. When homogenates prepared in phosphate buffer were frozen, much of their cholesteryl ester hydrolase activity was lost. Homogenates in Tris buffer, or supernatants prepared from these homogenates could, however, be frozen at $-80^{\circ} \mathrm{C}$ without loss of enzyme activity.

\section{Effects of cryptorchidism on cholesteryl ester hydrolase activity}

Secondary unilateral cryptorchidism in adult rats resulted in loss of about $30 \%$ of the enzyme activity from the abdominal testis in $24 \mathrm{~h}$ (Table 1), but testicular weight was unaffected. Rats made unilaterally cryptorchid at birth (primary cryptorchidism) had up to $75 \%$ lower activity in the abdominal testes compared to the contralateral scrotal testes, when examined at adult age (Table 1; Fig. 3).

Table 1. Cholesteryl ester hydrolase activity ( $\mu \mathrm{U} / \mathrm{mg}$ protein) in scrotal and abdominal testes from adult, primary and secondary unilaterally cryptorchid rats

\begin{tabular}{lccc}
\hline & $\begin{array}{c}\text { Secondary } \\
\text { cryptorchidism } \\
(\mathrm{N}=3)\end{array}$ & $\begin{array}{c}\text { Primary } \\
\text { cryptorchidism } \\
(\mathrm{N}=3)\end{array}$ & $\begin{array}{c}\text { Primary } \\
\text { cryptorchidism } \\
\text { EDS-treated } \\
(\mathrm{N}=5)\end{array}$ \\
\hline $\begin{array}{c}\text { Scrotal } \\
\text { testis } \\
\begin{array}{c}\text { Abdominal } \\
\text { testis }\end{array}\end{array}$ & $166 \pm 13 \cdot 3$ & $167 \pm 14 \cdot 9$ & $151 \pm 18 \cdot 4$ \\
\hline
\end{tabular}

Values are mean \pm s.e.m.

Treatment with EDS resulted in complete loss of Leydig cells, but no apparent morphological changes were noted in the tubules. In scrotal testis more than $90 \%$ of the hydrolase activity remained, indicating that the activity was located mainly in the Sertoli cells (Table 1). In contrast, treatment of adult (primary) unilaterally cryptorchid rats with EDS resulted in almost total disappearance of the hydrolase activity of the abdominal testes (Table 1). 


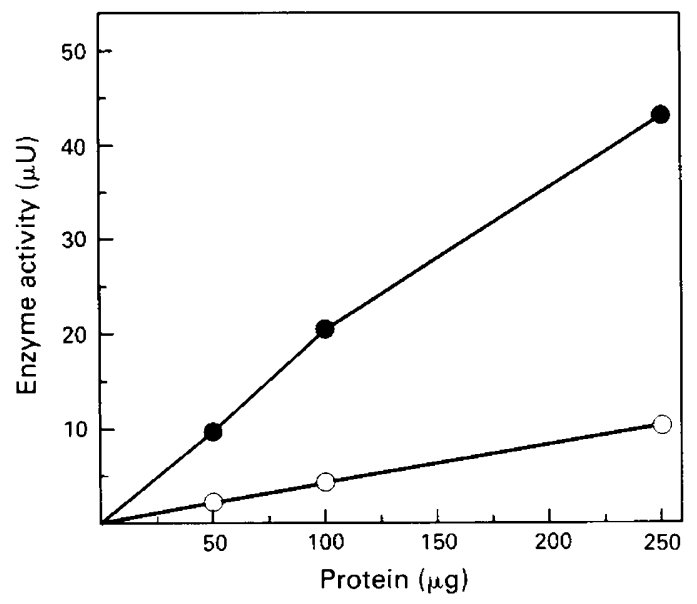

Fig. 3. Effect of primary experimental cryptorchidism on activity of cholesteryl ester hydrolase. Incubations were carried out in triplicate, and the activity is expressed in $\mu \mathrm{U}$.

When cholesteryl ester hydrolase activity was studied in primary unilaterally cryptorchid rats of increasing age, at 16 days the activity was significantly higher in the abdominal testes than in the corresponding scrotal testes. At 20 days the activity in the abdominal testes was about $30 \%$ lower than in the contralateral scrotal testes, and at 30 days it was $36 \%$ lower (Fig. 4a; Table 2).

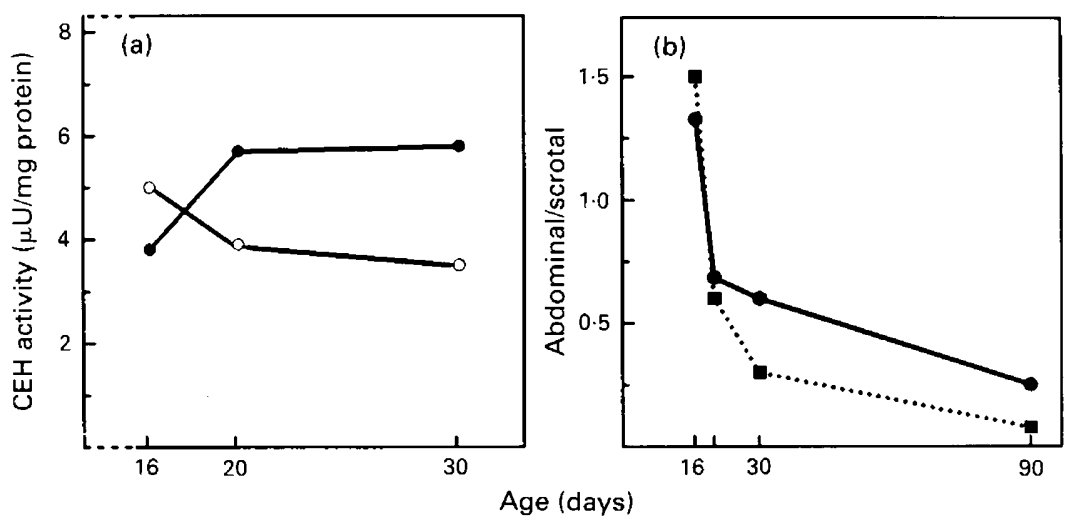

Fig. 4. Effect of primary experimental cryptorchidism on cholesteryl ester hydrolase activity in prepubertal rats. (a) Enzyme activity in scrotal (O) and abdominal $(O)$ testes; (b) enzyme activity in the scrotal testes divided by the activity in the abdominal testes. The ratio is plotted both for the activities per $\mathrm{mg}$ protein $(\boldsymbol{\bullet})$, and for the activities per whole tissue ( $\mathbf{\square}$ ).

The testicular weight also changed as a function of time (Table 3). At 16 days the weight of the abdominal testes was slightly higher (see also Bergh et al., 1987), whereas at 20 days, or later, it was lower than for the scrotal testes. These differences in weight compound the differences in enzyme activity per g tissue (Fig. 4a), and differences in total organ activity were even more pronounced (Fig. 4b). 
Table 2. Cholesteryl ester hydrolase activity ( $\mu \mathrm{U} / \mathrm{mg}$ protein) in scrotal and abdominal testes in unilaterally cryptorchid prepubertal rats

\begin{tabular}{lccc}
\hline & $\begin{array}{c}16 \text { days } \\
(\mathrm{N}=5)\end{array}$ & $\begin{array}{c}20 \text { days } \\
(\mathrm{N}=5)\end{array}$ & $\begin{array}{c}30 \text { days } \\
(\mathrm{N}=5)\end{array}$ \\
\hline Scrotal testis & $3 \cdot 8 \pm 0 \cdot 38$ & $5 \cdot 7 \pm 0 \cdot 50$ & $5 \cdot 8 \pm 0 \cdot 26$ \\
Abdominal testis & $5 \cdot 0 \pm 0 \cdot 54^{*}$ & $3 \cdot 9 \pm 0 \cdot 24^{*}$ & $3 \cdot 5 \pm 0 \cdot 30^{*}$ \\
\hline
\end{tabular}

Values are mean \pm s.d.

*Significantly different from scrotal testis $(P<0.05)$.

Table 3. Testicular weight $(\mathrm{mg})$ for scrotal and abdominal testes in prepubertal rats

\begin{tabular}{lccc}
\hline & $\begin{array}{c}16 \text { days } \\
(\mathrm{N}=5)\end{array}$ & $\begin{array}{c}20 \text { days } \\
(\mathrm{N}=5)\end{array}$ & $\begin{array}{c}30 \text { days } \\
(\mathrm{N}=5)\end{array}$ \\
\hline $\begin{array}{l}\text { Scrotal } \\
\text { testis }\end{array}$ & $57 \pm 3$ & $145 \pm 15$ & $569 \pm 40$ \\
$\begin{array}{c}\text { Abdominal } \\
\text { testis }\end{array}$ & $64 \pm 4$ & $129 \pm 20$ & $274 \pm 15^{*}$ \\
\hline $\begin{array}{l}\text { Mean } \pm \text { s.d. } \\
\text { *Significantly lower than value for the scrotal testis } \\
(P<0 \cdot 05) \text { according to Wilcoxon's signed value test } \\
\text { for paired observations. }\end{array}$
\end{tabular}

\section{Discussion}

The most obvious function for a testicular cholesteryl ester hydrolase would be to mobilize cholesterol from deposits in lipid droplets for steroid hormone biosynthesis. Hormone-sensitive hydrolases with this function are present in the adrenals and the ovaries (Mori \& Christensen, 1980; Cook et al., 1981, 1983), and preliminary studies suggest that testicular cholesteryl ester hydrolases share several properties with those enzymes (A. M. Hoffmann \& G. Fredriksson, unpublished). Previous studies have shown that Leydig cells and Sertoli cells have cholesteryl ester hydrolase activity (Durham \& Grogan, 1982), and in the present study we observe a marked increase in enzyme activity during sexual maturation, possibly due to gonadotrophin stimulation since both LH and FSH may stimulate this enzyme activity (Durham \& Grogan, 1984).

In this study the measured activity could have been in Leydig and Sertoli cells. Treatment with EDS resulted in loss of less than $10 \%$ of the total activity in scrotal testes. It is therefore likely that most of the activity measured in normal testis represents Sertoli cells. This is in accord with the fact that Leydig cells in normal testes constitute only $2-4 \%$ of the total testicular mass (Bergh \& Damber, 1978; Mori \& Christensen, 1980), and large changes in Leydig cells are therefore needed to affect the total cholesteryl ester hydrolase activity.

Since the function of Sertoli cells but not that of Leydig cells is influenced during the earliest phase of experimental cryptorchidism (Bergh \& Damber, 1978; Bergh, 1983), it is likely that the changes observed in this study primarily reflect changes in Sertoli cell hydrolase activity. In fact, treatment of primary cryptorchid rats with EDS resulted in an almost complete loss of cholesteryl ester hydrolase activity in the abdominal testis. This suggests that the enzyme activity in these testis 
was located primarily in the Leydig cells and that cryptorchidism had decreased this activity in Sertoli cells by more than $90 \%$.

Spermatogenesis cannot take place at normal body temperature, but the cellular mechanisms behind this remain unknown. Some investigators claim that the primary reason is that the function of some types of germ cells, particularly early spermatids and early primary spermatocytes, is inhibited at abdominal temperature (Lee \& Fritz, 1972; Nakamura \& Hall, 1978; Hall et al., 1985). Other investigators suggest that the primary target cell is the Sertoli cell, since Sertoli cell protein secretion in vivo and in vitro is inhibited by abdominal temperatures (Hagenäs et al., 1978; Rommerts et al., 1980; Steinberger, 1981). One early change that can be observed in cryptorchid testes is accumulation of lipid droplets in the cytoplasm of Sertoli cells, when experimental cryptorchidism is induced in immature or in adult rats (Bergh, 1981, 1983; Bergh \& Damber, 1984). This lipid accumulation is probably caused by a direct effect of cryptorchidism on Sertoli cell function since lipid accumulation is also noted early in experimentally cryptorchid testes that do not contain germ cells, e.g. because of irradiation in utero (Bergh, 1981).

Durham \& Grogan (1982) reported that Sertoli cells contain a cholesteryl ester hydrolase which is unstable at abdominal temperatures, and that the activity is decreased in the abdominal testes in secondary cryptorchidism. The present observation of a highly reduced hydrolase activity in experimentally cryptorchid testes is in agreement with their results, and with our observation of an increased lipid content in abdominal Sertoli cells (Bergh, 1981, 1983). However, the earliest change noted in this study was an increased cholesteryl ester hydrolase activity in the abdominal testes at 16 days of age. At this age Sertoli cells in some stages of the spermatogenic cycle contain an increased amount of lipid droplets, but apart from this, there are no morphological signs of Sertoli or Leydig cell malfunction (Bergh, 1983). On the contrary, tubule lumen formation, which is initiated by Sertoli cell fluid secretion, occurs earlier in the abdominal than in the scrotal testes, and the weight of the abdominal testis is slightly increased at this age (Bergh, 1983; Bergh et al., 1987). From 4 days later, degenerating germ cells are noted. The endoplasmic reticulum is dilated and the secretion of oestrogen, androgen binding protein and probably also inhibin are decreased (Bergh, 1983; Bergh et al., 1984). Moreover, as shown in this study the cholesteryl ester hydrolase activity is subnormal.

It appears that the earliest changes noted in abdominal testes could be an increased rather than decreased Sertoli cell function, raising the interesting possibility that the primary abnormality in abdominal testes could be some type of overactivity, which subsequently leads to degenerative changes. Our observations suggest that the initial increase and later decrease in cholesteryl ester hydrolase activity may not be a direct effect of temperature on this enzyme but probably secondary to other yet unknown mechanisms. Perhaps the synthesis or uptake of lipids is increased in the Sertoli cells of abdominal testes at 16 days of age and the increased enzyme activity could be a secondary response to this phenomenon. The increased enzyme activity at 16 days could also reflect an increase in Leydig cell activity, overshadowing the early decrease in Sertoli cells.

This work was supported by grants from the Swedish Medical Research Council (12X-5935 and 13X-727).

\section{References}

Bartke, A., Musto, N., Caldwell, B.W. \& Behrman, H.R. (1973) Effects of a cholesterol esterase inhibitor and of prostaglandin F2 $\alpha$ on testis cholesterol and on plasma testosterone in mice. Prostaglandins 3, 97-104.

Belfrage, P. \& Vaughan, M. (1969) Simple liquid-liquid partition system of labelled oleic acid from mixtures with glycerides. J. Lipid Res. 10, 341-344.
Bergh, A. (1981) Morphological signs of a direct effect of experimental cryptorchidism on Sertoli cells in rats irradiated as fetuses. Biol. Reprod. 24, 145-152.

Bergh, A. (1983) Early morphological changes in the abdominal testes in immature unilaterally cryptorchid rats. Int. J. Androl. 6, 73-90.

Bergh, A. \& Damber, J.E. (1978) Morphometric and functional investigation on the Leydig cells in 
experimental unilateral cryptorchism in the rat. Int. J. Androl. 1, 549-562.

Bergh, A. \& Damber, J.E. (1984) Local regulation of Leydig cells by the seminiferous tubules. Effect of short-term cryptorchidism. Int. J. Androl. 7, $409-418$.

Bergh, A. \& Helander, H.F. (1978) Testicular development in the unilaterally cryptorchid rat. Int. $J$. Androl. 1, 440-458.

Bergh, A., Helander, H.F. \& Wahlquist, L. (1978) Studies on factors governing testicular descent in the ratparticularly the role of gubernaculum testis. Int. $J$. Androl. 1, 342-356.

Bergh, A., Damber, J.E. \& Ritzén, M. (1984) Early signs of Sertoli and Leydig cell dysfunction in the abdominal testes of immature unilaterally cryptorchid rats. Int. J. Androl. 7, 398-408.

Bergh, A., Damber, J.E. \& Huhtaniemi, I. (1987) Intratesticular steroids and gonadotrophin receptors in the testes of immature unilaterally cryptorchid rats. Int. J. Androl. 10, 803-808.

Blackshaw, A.W. (1977) Temperature and seasonal influences. In The Testis, vol. 4, pp. 517-545. Eds A. D. Johnson and W. R. Gomes. Academic Press, New York.

Cook, K.G., Lee, F.-T. \& Yeaman, S.J. (1981) Hormonesensitive cholesterol ester hydrolase of bovine adrenal cortex: identification of the enzyme protein. FEBS Lett. 132, 10-14.

Cook, K.G., Colbran, R.J., Snee, J. \& Yeaman, S.J. (1983) Cytosolic cholesterol ester hydrolase from bovine corpus luteum. Its purification, identification and relationship to hormone-sensitive lipase. Biochim. Biophys. Acta 752, 46-53.

Davis, J.T. \& Coniglio, J.G. (1967) The effect of cryptorchidism, cadmium and anti-spermatogenic drugs on fatty acid composition of rat testis. J. Reprod. Fert. 14, 407-13.

Durham, L.A. \& Grogan, W.M. (1982) Temperature sensitivity of cholesteryl ester hydrolase in the rat testis. Lipids 17, 970-975.

Durham, L.A. \& Grogan, W.M. (1984) Characterization of multiple forms of cholesteryl ester hydrolase in the rat testis. J. Biol. Chem. 259, 7433-7438.

Fleeger, J.L., Bishop, J.P., Gomes, W.R. \& VanDemark, N.L. (1968a) Testicular lipids. I. Effects of unilateral cryptorchidism on lipid classes. J. Reprod. Fert. 15, $1-7$.

Fleeger, J.L., Bishop, J.P., Gomes, W.R. \& VanDemark, N.L. (1968b) Testicular lipids. II. Effect of unilateral cryptorchidism on fatty acids of testicular phospholipids and triglycerides. J. Reprod. Fert. 15, 9-14.

Fredrikson, G., Strålfors, P., Nilsson, N.Ö. \& Belfrage, P. (1981) Hormone-sensitive lipase from adipose tissue of rat. Methods Enzymol. 71, 636-646.
Hall, P.F., Kew, D. \& Mita, M. (1985) The influence of temperature on the function of cultured Sertoli cells. Endocrinology 116, 1926-1932.

Hagenäs, L., Ritzén, E.M. \& Suginami, H. (1978) Hormonal milieu of the seminiferous tubules in the normal and cryptorchid rat. Int. J. Androl. 1, 477-484.

Jackson, C.M. \& Morris, I.D. (1977) Gonadotrophin levels in male rats following impairment of Leydig cell function by ethylene dimethane sulphonate. Andrologia 9, 29-35.

Johnson, A.D., Gomes, W.R. \& VanDemark, N.L. (1971) Testicular Lipids. IV. Effect of unilateral and bilateral cryptorchidism on the fatty acids of esterified cholesterol in the rat and rabbit. J. Reprod. Fert. 25, 425-430.

Lee, L.P. \& Fritz, I.B. (1972) Studies on spermatogenesis in rat. V. Increased thermal lability of lysosomes from testicular germinal cells and its possible relationship to impairment in spermatogenesis in cryptorchidism. J. biol. Chem. 247, 7956-7961.

Lowry, O.H., Rosebrough, N.J., Farr, A.L. \& Randall, R.J. (1951) Protein measurement with the folinphenol reagent. J. biol. Chem. 193, 265-275.

McEnery, W.B. \& Nelson, W.O. (1953) Organic phosphorus compounds in testis of rat under experimental conditions which impair spermatogenesis. Endocrinology 52, 104-1 [4.

Mori, H. \& Christensen, A.K. (1980) Morphometric analysis of Leydig cells in the normal rat testis. $J$. Cell Biol. 84, 340-354.

Morris, I.D., Phillips, D.M. \& Bardin, C.W. (1986) Ethylene dimethanesulfonate destroys Leydig cells in the rat testis. Endocrinology 118, 709-719.

Moyle, W.R., Jungas, R.L. \& Greep, R.O. (1973) Metabolism of free and esterified cholesterol by Leydig-cell tumour mitochondria. Biochem. J. 134, 415424.

Nakamura, M. \& Hall, P.F. (1978) The influence of temperature upon polysomes of spermatids of rat testes. Biochem. Biophys. Res. Commun. 85, 756-761.

Rommerts, F.F., de Jong, F.H., Grootegoed, J.A. \& van der Molen, H.J. (1980) Metabolic changes in testicular cells from rats after long-term exposure to $37^{\circ} \mathrm{C}$ in vivo or in vitro. J. Endocr. 85, 471-479.

Saksena, S.K., Lau, I.F. \& Bartke, A. (1974) Prostaglandins $\mathrm{A} 1$ and $\mathrm{A} 2$ decrease testosterone levels in mice and rats. Endocrinology 95, 311-314.

Steinberger, E. (1981) Current status of studies concerned with evaluation of toxic effects of chemicals on the testes. Environ. Health Perspect. 38, 29-33.

VanDemark, N.L. \& Free, M.J. (1970) Temperature effects. In The Testis, vol. 3, pp. 233-312. Eds A. D. Johnson, W. R. Gomes \& N. L. Van Demark. Academic Press, New York.

Received 31 May 1988 